Article

\title{
Evaluation of the Spoilage-Related Bacterial Profiles of Vacuum-Packaged Chilled Ostrich Meat by Next-Generation DNA Sequencing Approach
}

\author{
Edyta Juszczuk-Kubiak ${ }^{1, *(\mathbb{D})}$, Agnieszka Dekowska ${ }^{1}$, Barbara Sokołowska ${ }^{1} \mathbb{D}$, Marzena Połaska $^{1}$ \\ and Krzysztof Lendzion ${ }^{2}$ \\ 1 Department of Microbiology, Prof. Wacław Dabrowski Institute of Agricultural and Food \\ Biotechnology—State Research Institute, Rakowiecka 36, 02-532 Warsaw, Poland; \\ agnieszka.dekowska@ibprs.pl (A.D.); barbara.sokolowska@ibprs.pl (B.S.); marzena.polaska@ibprs.pl (M.P.) \\ 2 Strusia Kraina \& Mobax Sp.j., Magazynowa 21, 40-424 Katowice, Poland; klendzion13@gmail.com \\ * Correspondence: edyta.juszczuk-kubiak@ibprs.pl
}

check for updates

Citation: Juszczuk-Kubiak, E.; Dekowska, A.; Sokołowska, B. Połaska, M.; Lendzion, K. Evaluation of the Spoilage-Related Bacterial Profiles of Vacuum-Packaged Chilled Ostrich Meat by Next-Generation DNA Sequencing Approach. Processes 2021, 9, 803. https://doi.org/ $10.3390 /$ pr9050803

Academic Editor: Umezuruike Linus Opara

Received: 31 March 2021

Accepted: 30 April 2021

Published: 3 May 2021

Publisher's Note: MDPI stays neutral with regard to jurisdictional claims in published maps and institutional affiliations.

Copyright: (C) 2021 by the authors. Licensee MDPI, Basel, Switzerland. This article is an open access article distributed under the terms and conditions of the Creative Commons Attribution (CC BY) license (https:// creativecommons.org/licenses/by/ $4.0 /)$

\begin{abstract}
Monitoring the development of the bacterial community in packaged raw meat refrigerated until two weeks is important for identifying the spoilage-related bacteria, preventing meat putrefaction, and prolong the shelf life. This study aimed to evaluate the influence of vacuum-packaging (VP) on the development of spoilage-related bacterial profiles in chilled ostrich meat among three manufacturing batches produced in different periods by using culture-dependent and 16S rDNA amplicon sequencing. Similar to the culture-dependent method, $16 \mathrm{~S}$ rDNA sequencing showed that Photobacterium was the most prevalent genus detected in VP ostrich meat after 14 days of cold storage. The second-largest group was the population of lactic acid bacteria (LAB), mainly dominated by Carnobacteriaceae including Carnobacterium spp. and Lactobacillaceae with Lactobacillus spp. Our results suggest that these taxa could contribute to spoilage of VP ostrich meat and shorten its shelf life, especially Photobacterium spp., which is considered as a potential meat spoiler.
\end{abstract}

Keywords: ostrich meat; vacuum packaging; $16 \mathrm{~S}$ rDNA sequencing; bacterial community

\section{Introduction}

In Poland, ostrich (Struthio camelus) breeding was started in 2000, and currently, ostrich meat production is one of the important segments of the food industry, mostly focused on export to the EU. Ostrich meat is one of the most popular choices in western societies because it is frequently described as a healthy alternative to beef and pork products, due to its favourable nutritional properties, such as low cholesterol and intramuscular fat contents and a high percentage of polyunsaturated fatty acids [1-3]. Moreover, ostrich meat has the characteristic of lower sodium and higher iron contents than other red meat such as beef; therefore, it is recommended for people with arterial hypertension and anaemia problems [4]. Currently, ostrich meat is considered ideal game meat for consumers who prefer a healthy eating style [2,3,5]. The relatively high $\mathrm{pH}(6.0-6.7)$ of ostrich meat creates an ideal environment for rapid microbial spoilage under some packaging conditions [6-8]. Therefore, extending the shelf life of ostrich meat products is a major concern for the ostrich industry [8]. To allow competitive marketing of ostrich meat, both for internal consumption and for export, it is necessary to know its microbial characteristics under different conditions to prolong its shelf life.

Modern meat packaging techniques are intended to maintain the microbial and sensory quality of the foodstuffs and extending their shelf life by inhibition or regarding the growth of undesirable microbiota. Vacuum packaging (VP) and storage under chilled conditions have proved to be very effective for extending the shelf life of various perishable foods, including meat [9]. This method of packaging can prevent the growth of some 
food-borne pathogens and spoilage bacteria commonly present on meat and therefore is widely used for packaging primal cuts for distribution to the retail market $[10,11]$. Recently, several studies have focused on describing the diversity of the spoilage microbial population in response to different meat storage conditions [12,13]. According to the literature, the predominant genera associated with freshly beef, pork, and poultry spoilage are Brochothrium thermosphacta, Enterobacteriaceae, Pseudomonas spp., and lactic acid bacteria (LAB) $[8,13,14]$, defined as ephemeral spoilage organisms (ESOs) [15]. Several studies have clearly shown that storage temperature combined with packaging conditions induces a selection of spoilage microbiota, such as ESOs, consequently limiting the spoilage process and determining the commercial shelf life of meat products $[12,13,15,16]$.

The basic knowledge of microbial populations that develops during the storage of raw ostrich meat under different refrigerated conditions and packaging techniques has been vested in the past by using culture-dependent studies $[6,8,9,14,17]$. According to mentioned trials, different ways of packaging as well as storage temperature and time, affect the microbiological abundance of ostrich meat. In several studies, it has been shown a decline in the number of aerobic bacteria under the conditions of VP, modified atmosphere (MAP), and MAP + CO during the first 4 days of storage, and a significant increase in the subsequent stages of storage $[6,8,9,17]$. Fernandez-Lopez et al. [17] reported that ostrich meat stored under aerobic conditions would have a shelf life of 8 days, while under vacuum, or modified atmospheres (MAP or MAP + CO) it would be 12 days. On the other hand, Otremba et al. [18] showed that the previously frozen $\left(-40^{\circ} \mathrm{C}\right)$, VP ostrich meat stored under refrigerated conditions for 14 days should be used within 10 days; although microbial growth remained below 7 logs CFU/g for up to 21 days, the unacceptable aroma and colour of meat occurred after 14 days of refrigerated storage. Moreover, in a culturedependent study, Alonso-Calleja et al. [6] reported that Pseudomonas spp., Enterobacteriaceae and LABs are initial microbiota in fresh ostrich steaks, and VP treatment is an effective method of inhibiting Pseudomonas spp. growth. Similarly, Bingol and Ergun [7] reported that packaging of ostrich meat under a MAP effectively inhibited the growth of Pseudomonas sp., but a significant increase in the number of $\mathrm{LAB}$ was observed during the storage period which was consistent with the previously reported studies [6,8,9]. It should be emphasised that feeding, slaughter environment, and contamination of carcass are important factors shaping the structure of the initial microflora of raw meat and affect the final quality of meat products and their shelf life. Therefore, it is necessary to analyse the microflora of raw meat from the regional commercial farm, especially ostrich meat as a new, less popular product on the retail market.

In recent years, the development and application of molecular techniques such as $16 \mathrm{~S}$ rDNA amplicon sequencing using the next-generation sequencing (NGS) approach have become a useful tool for the identification and monitoring of bacterial community changes in packaged and chilled-stored meat products. Many studies using the $16 \mathrm{~S}$ rDNA sequencing to characterise the spoilage-related microflora of beef [15], pork $[19,20]$, and poultry meat [21-23] stored under aerobic conditions or in vacuum packs have been reported. For example, Xiao, Dong, Zhu, and Cui [24], using 454 pyrosequencing, found that bacterial diversity of vacuum-packaged pork meat increased during refrigerated storage. Using $16 \mathrm{~S}$ rDNA amplicon sequencing, Li et al. [25] determined the profile of potential spoilagerelated bacteria as well as the dynamics of their changes to predict the shelf life of pork meat during storage under refrigerated conditions. Although there are a lot of studies focused on the composition of the bacterial community in meat products [14], little is known about the bacterial diversity on the level of the meat production plant, manufacturing batch variation, and microbial changes that occur during and after storage [13,26].

However, to date, there is no metagenomics report on the microbial community present in vacuum-packed ostrich meat stored in refrigerated conditions for two weeks, which is offered in the retail market. The objective of this study was to determine the microbial community composition and diversity of vacuum-packaged chilled ostrich meat among three manufacturing batches produced in different periods and stored 14 days at 
$4-5{ }^{\circ} \mathrm{C}$ using culture-independent $16 \mathrm{~S}$ rDNA sequencing. Moreover, a culture-dependent method for enumeration of common spoilage bacteria in ostrich meat was also used. In our study, we especially were interested in the volatility of community composition among different batches of ostrich meat sampled at three manufacturing periods (August, October, March) to investigate spoilage-related bacteria profiles and provide a more comprehensive evaluation of the microbial quality of ostrich meat products.

\section{Material and Methods}

\subsection{Meat Samples}

Three batches of ostrich meat (steak and fillet) originating from three different manufacturing periods: August 2019 (batch I), October 2019 (batch II), and March 2020 (batch III) were analysed. Meat samples were obtained from the meat processing company Strusia Kraina \& MOBAX Sp.j. (Katowice, Poland) from ostrich with a preslaughter weight of 90 to $130 \mathrm{~kg}$. After overnight chilling at a temperature of $-2{ }^{\circ} \mathrm{C}$ to $0{ }^{\circ} \mathrm{C}$, approximately $300 \mathrm{~g}$ of fillet and steaks were collected from three randomly selected ostrich carcasses. During cutting and packing $(8 \mathrm{~h})$, the meat was at a temperature of from $2{ }^{\circ} \mathrm{C}$ to $4{ }^{\circ} \mathrm{C}$. The ostrich meat samples were packed in $40 \mu \mathrm{m}$ multilayer barrier bags with a PET/PA/EVOH/PE structure (OTR: O2 $23 \mathrm{cc} / \mathrm{m}^{2} / 24 \mathrm{~h}$; Bag supplier: Mercur Group, Poland) on a vacuum machine (Tepro PP12; Tepro S.A. Poland) and were placed into sterile containers and transported out in a compressor refrigerator (CFX3 75 Dometic) at $0{ }^{\circ} \mathrm{C}$ to the laboratory within $5 \mathrm{~h}$. The meat delivered to the laboratory was at a temperature of $3^{\circ} \mathrm{C}$ to $4{ }^{\circ} \mathrm{C}$. Then, samples of steak and fillet were stored in the refrigerator for 14 days at $4-5^{\circ} \mathrm{C}$.

To investigate the effect of microbial differences between production batches, 24 packages were prepared for each batch. A total of 12 packages (six fillets and six steaks) were used for the initial microbial enumeration (two biological replicates). For VP treatment, 12 packages were prepared; two packages of both fillet and steak for each batch (two biological replicates) were used for $16 \mathrm{~S}$ rDNA analysis.

\subsection{Microbiological Analysis}

Microbiological analysis was carried out immediately after delivery (for initial microbial load evaluation) of meat samples and after 14 days of refrigerated storage (final microbial load evaluation). Briefly, $20 \mathrm{~g}$ of ostrich fillet and separately steak from each batch were blended (Stomacher Colworth 400) for $2 \mathrm{~min}$ in $180 \mathrm{~mL}$ of tryptone salt broth $(0.85 \%(w / v) \mathrm{NaCl}, 0.1 \%(w / v)$ tryptone, Biokar Diagnostics, Beauvais, France) according to ISO 6887-1 and 4:2017 to prepare an initial suspension. Decimal dilutions were carried out using the same diluent. Culture media and incubation parameters used are shown in Table 1. Duplicate plates were incubated under aerobic conditions. Confirmation of Enterobacteriaceae, Pseudomonas, and LABs was carried out according to ISO standards (glucose fermentation test, oxidase reactions, and catalase). The results were expressed as $\log \mathrm{CFU} / \mathrm{g}$. The assays were performed using two independent samples of the fillet $(n=6)$ and two independent samples of the steak $(n=6)$ for each batch. 
Table 1. Culture media, incubation times, temperatures, and references for microbiological analysis.

\begin{tabular}{|c|c|c|c|c|}
\hline \multirow{2}{*}{ Microbial Group } & \multirow{2}{*}{ Culture Medium } & \multicolumn{2}{|c|}{ Incubation } & \multirow{2}{*}{ References } \\
\hline & & Temp. $\left({ }^{\circ} \mathrm{C}\right)$ & Time (h) & \\
\hline $\begin{array}{c}\text { Presumptive } \\
\text { Photobacterium sp. }\end{array}$ & $\begin{array}{l}\text { Marine Agar (Difco } \\
\text { Becton Dickinson } \\
\text { Sparks MD. USA) }\end{array}$ & 15 & 72 & [27] \\
\hline $\begin{array}{l}\text { Lactic acid bacteria } \\
(\mathrm{LAB})^{\mathrm{a}}\end{array}$ & $\begin{array}{c}\text { Man. Rogosa. Sharpe } \\
\text { (MRS) agar (Merck, } \\
\text { Darmstadt, Germany) }\end{array}$ & 30 & 72 & ISO 15214:1998 \\
\hline Brochothrix spp. ${ }^{b}$ & $\begin{array}{l}\text { Streptomycin, sulphate } \\
\text { thallous acetate agar } \\
\text { (STAA) (Oxoid } \\
\text { Basingstoke, UK) }\end{array}$ & 25 & 48 & ISO 13722:2017 \\
\hline Pseudomonas spp. ${ }^{\mathrm{b}}$ & $\begin{array}{l}\text { Pseudomonas agar } \\
\text { supplemented with } \\
\text { cetrimide. fucidin. } \\
\text { cephalosporin (CFC) } \\
\text { (Merck, Darmstadt, } \\
\text { Germany) }\end{array}$ & 25 & 72 & ISO 13720:2010 \\
\hline Enterobacteriaceae $^{\mathrm{c}}$ & $\begin{array}{l}\text { Violet red bile glucose } \\
\text { agar (VRBGA) (Graso } \\
\text { Biotech., Poland) }\end{array}$ & 37 & 24 & ISO 21528-2:2017 \\
\hline
\end{tabular}

\section{3. $16 \mathrm{~S}$ rDNA Amplicon Sequencing}

\subsubsection{DNA Extraction}

DNA was extracted from ostrich meat $(n=12)$ after 14 days of storage in a VP according to the method described by Rouger et al. [28]. Briefly, about $200 \mathrm{~g}$ of steak and fillet samples were placed in sterile filter bags, and $200 \mathrm{~mL}$ sterile TS buffer $(8.5 \mathrm{~g} / \mathrm{L} \mathrm{NaCl}$, $1 \mathrm{~g} / \mathrm{L}$ tryptone, $1 \%$ Tween 80 ) was added, followed by $5 \mathrm{~min}$ of hand agitation to separate the microflora from the meat surface. The filtrates from the bags were centrifuged in sterile Falcon containers $\left(4000 \times g, 20 \mathrm{~min}\right.$ at $\left.4^{\circ} \mathrm{C}\right)$, and the pellet was resuspended in $100 \mathrm{~mL}$ TS buffer. Total DNA was extracted using the DNeasy PowerFood Microbial Kit (Qiagen, $\mathrm{GmbH}$, Hilden, Germany) according to the protocol. DNA purity was measured by the Nanodrop ND-1000 Spectrophotometer (Thermo Fisher Scientific, Watertown, MA, USA), and DNA concentration was quantified by a Qubit 4.0 Fluorometer using the Qubit dsDNA BR Assay Kit (Invitrogen, Carlsbad, CA, USA). DNA samples were stored at $-20{ }^{\circ} \mathrm{C}$ until further processing for $16 \mathrm{~S}$ rDNA amplicon sequencing analysis.

\subsubsection{PCR Amplification of $16 \mathrm{~S}$ rDNA Genes}

For each sample, $5 \mathrm{ng}$ of total DNA, and one pair of primers (341F: CCTACGGGNGGC WGCAG-3'; 805R: GACTACHVGGGTATCTAATCC-3') were used to amplify the V3-V4 region of the $16 \mathrm{~S}$ rDNA gene. PCR was conducted using KAPA HiFi HotStart ReadyMix (KAPA Biosystems, Wilmington, MA, USA) and $10 \mu \mathrm{M}$ of each forward and reverse primer. PCR assay consisted of $95{ }^{\circ} \mathrm{C} / 3 \mathrm{~min}, 25$ cycles of $95{ }^{\circ} \mathrm{C} / 30 \mathrm{~s}, 56{ }^{\circ} \mathrm{C} / 30 \mathrm{~s}$, and $72{ }^{\circ} \mathrm{C} / 30 \mathrm{~s}$, followed by $72{ }^{\circ} \mathrm{C} / 5 \mathrm{~min}$. A negative control without template DNA was also included in the PCR assay. Amplicons were purified using MagSi-NGS ${ }^{\text {PREP}}$ PLUS (Steinbrenner Laborsysteme, GmbH, Wiesenbach, Germany) and quantified using the Qubit DNA BR Assay Kit (Invitrogen, Carlsbad, CA, USA) in conjunction with a Qubit 4.0.

\subsubsection{Library Preparation and Sequencing}

The 16S rDNA fragments were indexed using the Nextera XT Kit (Illumina, San Diego, CA, USA) according to the Nextera DNA Sample Preparation Guide (protocol \#15044223). Each index PCR reaction contained $5 \mu \mathrm{L}$ of the i7 and i5 adapter, $10 \mu \mathrm{L}$ of KAPA HiFi 
HotStart ReadyMix, $20 \mu \mathrm{L}$ of template DNA $(7.0 \mathrm{ng} / \mu \mathrm{L})$, and $10 \mu \mathrm{L}$ of $\mathrm{H}_{2} \mathrm{O}$ for a total reaction volume of $50 \mu \mathrm{L}$. The indexed PCR was cycled according to the Nextera DNA Sample Prep Guide, and the libraries were cleaned up using MagSi-NGS ${ }^{\text {PREP }}$ PLUS (Steinbrenner Laborsysteme, $\mathrm{GmbH}$, Wiesenbach, Germany). The DNA libraries were quantified using the Qubit 4.0 along with the Qubit DNA HS Assay Kit, and the quality was assessed on a TapeStation 4200 using the High Sensitivity D1000 SreenTape Assay Kit (Agilent, Santa Clara, CA, USA). Indexed libraries were normalised to $4 \mathrm{nM}$ and pooled. The normalised, pooled $4 \mathrm{nM}$ library was denatured using $0.2 \mathrm{~N} \mathrm{NaOH}$ and diluted to $10 \mathrm{pM}$ using prechilled HT1 buffer supplied in Nextera XT Kit (Illumina). The 10\% of denatured PhiX library (Illumina, San Diego, CA, USA) was spiked into the denatured and indexed library, which was loading into Illumina Miseq v3 reagent cartridge, and 16S rDNA gene amplicons were sequenced on an Illumina MiSeq platform using the 600 cycles $(2 \times 300 \mathrm{bp})$ v3 chemistry.

\subsubsection{Sequencing Data Analysis}

Bioinformatic analysis was performed using the CLC genomic workbench v.8.5.1 with Microbial Genomics Module (Qiagen) [29]. Briefly, for microbial community analysis, obtained raw paired-end reads were assembled and filtered for quality (max error rate $1 \%$ ) and length (minimum 300 bp of merged reads). Low-quality scores and chimeric reads were deleted using the USEARCH (http:/ / www.drive5.com/ usearch (accessed on 2 May 2021)). The merged sequences were trimmed of barcodes and primers and next the high-quality sequences were clustered into operational taxonomic units (OTUs) (Table S1). A sensitive BLASTN search against the GreenGenes 16S sequence database, v.13.5 (http:/ / greengenes. lbl.gov (accessed on 1 May 2019)) to obtain taxonomy assignment [30] was utilised.

\subsection{Statistical Analysis}

The software TIBCO Statistica ${ }^{\mathrm{TM}}$, version 13.5 (TIBCO Software Inc, Palo Alto, CA 94303, USA) was used to perform the statistical analysis. Analysis of variance (ANOVA) and Tukey's multiple range test was used to test the significance of differences $(p<0.05)$ between the mean log values of different manufacturing batches and time of storage. Statistically significant differences for each batch depending on family/genus and individually for each genus depending on the batch were determined using one-way ANOVA. If significant differences were found, the Fisher's NIR tests were performed. The occurrence of significant differences for interactions (family/genus $\times$ batch) was performed using a two-way ANOVA. To find out which interactions there were statistically significant, the NIR test was also performed. Data were presented as means \pm SD (standard deviation), and a value of $p<0.05$ was used to indicate statistical significance.

\section{Results}

\subsection{Bacterial Enumeration of Initial and VP Meat}

Microbial counting was performed to determine the number of culturable bacteria present. The changes in microbial populations in ostrich meat separately for ostrich fillet and steak are given in Table S2. A culture-dependent method was carried out to enumerate Brochotrix spp., LABs, Enterobacteriaceae, and Pseudomonas spp. as common spoilers in raw meat. Moreover, enumeration of presumptive Photobacterium spp. was also determined. The average of bacteria enumeration in ostrich meat (mean values from fillet and steak) considered as spoilage is presented in Table 2. Initial Photobacterium spp. count was not significantly different in all tested batches, but after 14 days of VP storage, a significant increase from $7.40 \mathrm{log}$ CFU/g to $7.85 \log$ CFU/g was observed $(p<0.05)$. Similarly, a significant increase $(p<0.05)$ of LAB counts after 14 days of storage in VP was determined in batch I (August; $5.70 \mathrm{log}$ CFU/g) and batch II (October; $6.15 \log$ CFU/g), respectively. Brochotrix spp. did not show a significant development within all batches $(p>0.05)$, remaining constant after 14 days of packaging. Nonetheless, the significantly highest count of Brochotrix spp. $(p<0.05)$ was observed in batch III $(4.73 \mathrm{log}$ CFU/g) in 
comparison with batch I (2.66 log CFU/g) and batch II (3.27 log CFU/g). Similarly, the initial count of Pseudomonas spp. was very low $(<1.00-1.87 \log \mathrm{CFU} / \mathrm{g})$ and remained at this level after 14 days of storage. The level of initial contamination of ostrich meat with Enterobacteriaceae was similar between all batches and the count of these bacteria was increased significantly to 5.02-5.62 log CFU/g $(p<0.05)$ at 14 days of storage; no significant differences in Enterobacteriaceae count related to the manufacturing batches were observed.

Table 2. Microbial analysis of initial and VP bacterial populations in refrigerated ostrich meat.

\begin{tabular}{|c|c|c|c|c|c|c|c|c|c|c|}
\hline \multirow{4}{*}{ Meat } & \multicolumn{10}{|c|}{ Colony Count (log CFU/g) } \\
\hline & \multicolumn{2}{|c|}{ Photobacterium spp. } & \multicolumn{2}{|c|}{ LAB } & \multicolumn{2}{|c|}{ Brochotrix spp. } & \multicolumn{2}{|c|}{ Pseudomonas spp. } & \multicolumn{2}{|c|}{ Enterobacteriaceae } \\
\hline & \multicolumn{10}{|c|}{ Storage Days } \\
\hline & Initial & 14 Days & Initial & 14 Days & Initial & 14 Days & Initial & 14 Days & Initial & 14 Days \\
\hline Batch I & $4.95 \pm 0.13 \mathrm{aA}$ & $7.40 \pm 0.08 \mathrm{bA}$ & $3.10 \pm 0.30 \mathrm{aA}$ & $6.15 \pm 0.00 \mathrm{bB}$ & $1.80 \pm 0.45 \mathrm{aA}$ & $2.66 \pm 0.24 \mathrm{aA}$ & $<1.00 \mathrm{aA}$ & $1.48 \pm 0.67 \mathrm{aA}$ & $2.47 \pm 0.51 \mathrm{aA}$ & $5.02 \pm 0.03 \mathrm{bA}$ \\
\hline Batch II & $5.12 \pm 0.05 \mathrm{aA}$ & $7.65 \pm 0.05 \mathrm{bAB}$ & $2.75 \pm 0.15$ aA & $5.70 \pm 0.48 \mathrm{bAB}$ & $1.82 \pm 0.47 \mathrm{aA}$ & $3.27 \pm 0.43 \mathrm{aAB}$ & $1.87 \pm 0.12 \mathrm{aB}$ & $1.73 \pm 0.18 \mathrm{aA}$ & $2.91 \pm 0.41 \mathrm{aA}$ & $5.62 \pm 0.30 \mathrm{bA}$ \\
\hline Batch III & $4.15 \pm 1.05 \mathrm{aA}$ & $7.85 \pm 0.08$ bB & $3.56 \pm 0.68$ aA & $4.78 \pm 0.10 \mathrm{aA}$ & $2.02 \pm 0.08 \mathrm{aA}$ & $4.73 \pm 0.45 \mathrm{bB}$ & $0.54 \pm 0.66 \mathrm{aAB}$ & $1.65 \pm 0.07 \mathrm{aA}$ & $1.70 \pm 0.06 \mathrm{aA}$ & $5.56 \pm 0.07 \mathrm{bA}$ \\
\hline
\end{tabular}

a-b Mean values in rows with different lowercase letters are significantly different at $p<0.05$, separately for the microbial counts of each group and each batch. A-B Mean values in columns with different capital letters are significantly different at $p<0.05$, separately for the microbial counts of each group and day of storage. Data are mean \pm standard deviation.

\section{2. $16 S$ rDNA Sequencing Data of VP Meat}

16S rDNA amplicoVn sequencing was used to gain insight into the composition of the bacterial community in VP ostrich meat after 14 days of storage at $4-5^{\circ} \mathrm{C}$ and was performed separately for ostrich steak and fillet (Table 3).

Table 3. Comparison of bacterial community composition at the family/genus level (\%) in ostrich steak and fillet between three manufacturing batches after 14 days of refrigerated storage.

\begin{tabular}{|c|c|c|c|c|c|c|c|c|c|c|c|c|}
\hline \multirow{2}{*}{ Family/Genus } & \multicolumn{2}{|c|}{ Steak I } & \multicolumn{2}{|c|}{ Steak II } & \multicolumn{2}{|c|}{ Steak III } & \multicolumn{2}{|c|}{ Fillet I } & \multicolumn{2}{|c|}{ Fillet II } & \multicolumn{2}{|c|}{ Fillet III } \\
\hline & $\mathbf{N}$ & $\%$ & $\mathbf{N}$ & $\%$ & $\mathbf{N}$ & $\%$ & $\mathbf{N}$ & $\%$ & $\mathbf{N}$ & $\%$ & $\mathbf{N}$ & $\%$ \\
\hline Vibrionaceae/Photobacterium & $60,540.0$ & 85.63 & $52,126.0$ & 87.71 & $52,997.0$ & 47.22 & $65,651.0$ & 83.47 & $41,658.0$ & 91.77 & $62,198.0$ & 65.31 \\
\hline $\begin{array}{c}\text { Carnobacteriaceae/ } \\
\text { Carnobacterium }\end{array}$ & 494.0 & 0.70 & $1,550.0$ & 2.61 & $17,533.0$ & 15.62 & 1013.0 & 1.29 & 1520.0 & 3.35 & 8749.0 & 9.19 \\
\hline Carnobacteriaceae/Other & - & - & - & - & $22,224.0$ & 19.80 & - & - & - & - & 9852.0 & 10.35 \\
\hline Lactobacillaceae/Lactobacillus & 3320.0 & 4.70 & $4,078.0$ & 6.86 & 2474.0 & 2.20 & 2125.0 & 2.70 & 1051.0 & 2.32 & 1924.0 & 2.02 \\
\hline Enterobacteriaceae/Serratia & - & - & - & - & - & - & 657.0 & 0.84 & - & - & - & - \\
\hline Enterobacteriaceae/Other & - & - & 494.0 & 0.83 & 5564.0 & 4.96 & - & - & 594.0 & 1.31 & 3061.0 & 3.21 \\
\hline Streptococcaceae/Lactococcus & - & - & - & - & 3023.0 & 2.69 & - & - & - & - & 3785.0 & 3.97 \\
\hline Enterococcaceae/Vagococcus & - & - & - & - & - & - & - & - & 101.0 & 0.22 & - & - \\
\hline Leuconostocaceae/Weissella & 530.0 & 0.75 & 650.0 & 1.09 & - & - & 720.0 & 0.92 & 67.0 & 0.15 & - & - \\
\hline Shewanellaceae/Shewanella & 1241.0 & 1.76 & - & - & - & - & 859.0 & 1.09 & - & - & - & - \\
\hline Bacteroidaceae/Bacteroides & 492.0 & 0.70 & - & - & - & - & - & - & - & - & - & - \\
\hline Unidentified & 2607.0 & 3.69 & 250.0 & 0.42 & 7546.0 & 6.72 & 4745.0 & 6.03 & & & 5050.0 & 5.30 \\
\hline
\end{tabular}

I-August; II-October; III-March; N—the average number of reads (read counts); \%—the average total reads.

Results showed that the majority of bacterial sequences $(>0.5 \%)$ identified in samples of ostrich meat after 14 days of storage belonged to Photobacterium, Lactobacillus, Carnobacterium, Serratia, Shewanella, Weissella, Vagococcus, Bacteroides, and Lactococcus (Table 4). Similar to culture-dependent analysis, Photobacterium spp. constituted the most predominant microflora in all ostrich meat batches, but the highest relative abundance in batch I $(84.55 \%)$ and batch II $(89.74 \%)$ was found $(p<0.05)$ (Table 5$)$. The microbial community of batch III was also dominated by Photobacterium spp. with a relative abundance of more than $65 \%$ in the fillet and $47 \%$ in the steak, respectively. The results of our study also revealed a dominance of the $\mathrm{LAB}(28 \%)$ population in ostrich meat after 14 days of storage in a vacuum package under chilled conditions. The LAB population consisted of Carnobacteriaceae (20.5\%), Lactobacillaceae (3.5\%), Streptococcaceae (3.3\%) Leuconostocaceae $(0.7 \%)$ and was mainly dominated by Carnobacterium (5.39\%) and Lactobacillus (3.5\%) genus (Table 4). A relatively high abundance of Carnobacterium spp. was obtained in the manufacturing batch III, compared with batches I and II ( $p<0.05)$ (Table 5). Moreover, both samples from batch III showed a relatively high abundance of psychrotrophic Lactococcus spp. (3.97\% 
and $2.69 \%$ ) and a relatively low proportion of Lactobacillus spp. in the steak (2.2\%) in comparison with the steak from batch I (4.7\%) and II (6.86\%) (Table 3). The rest of the LAB population, i.e., Weissella spp. remained at a low level and was detected in the fillet and steak from batch I (0.92\%/0.75\%) and batch II (0.15\%/1.09\%). In our study, after 14 days of storage, Enterobacteriaceae were identified with relatively low abundance in the fillet from batch I ( $0.84 \%)$ and were more abundant in batch III in both the fillet $(3.21 \%)$ and the steak (4.96\%) (Table 3). Serratia spp. belonging to Enterobacteriaceae was found in this study but was presented only in the fillet from batch I with a detection limit of $0.84 \%$. Relative abundances of Brochotrix spp. and Pseudomonas spp. were below to detection limit and were not found in VP ostrich meat after 14 days of storage.

Table 4. Average share (\%) of OTU assigned to bacterial taxonomic units between batches of ostrich meat from different manufacturing periods after 14 days of refrigerated storage.

\begin{tabular}{|c|c|c|c|c|}
\hline \multirow[t]{2}{*}{ Family/Genus } & $\begin{array}{l}\text { Batch I } \\
\text { (August) }\end{array}$ & $\begin{array}{l}\text { Batch II } \\
\text { (October) }\end{array}$ & Batch III (March) & $\begin{array}{l}\text { Relative Abundances } \\
\qquad(\mathrm{I}+\mathrm{II}+\mathrm{III}) *\end{array}$ \\
\hline & $(\%)$ & $(\%)$ & $(\%)$ & $(\%)$ \\
\hline Vibrionaceae/Photobacterium & 84.55 & 89.74 & 56.27 & 76.85 \\
\hline Carnobacteriaceae/other & - & - & 15.08 & 15.08 \\
\hline Carnobacteriaceae/Carnobacterium & 1.00 & 2.98 & 12.21 & 5.39 \\
\hline Enterobacteriaceae/other & - & - & 4.09 & 4.09 \\
\hline Lactobacillaceae/Lactobacillus & 3.7 & 4.7 & 2.11 & 3.50 \\
\hline Streptococcaceae / Lactococcus & - & - & 3.33 & 3.33 \\
\hline Shewanellaceae/Shewanella & 1.43 & - & - & 1.43 \\
\hline Enterococcaceae/Vagococcus & - & 1.35 & - & 1.35 \\
\hline Leuconostocaceae/Weissella & 0.84 & 0.62 & - & 0.73 \\
\hline Enterobacteriaceae/Serratia & 0.84 & - & - & 0.84 \\
\hline Bacteroidaceae / Bacteroides & 0.7 & - & - & 0.70 \\
\hline Unclassified & 4.86 & 0.475 & 6.01 & 3.78 \\
\hline
\end{tabular}

* mean of (\%) abundances from three manufacturing batches.

Table 5. Mean of relative abundances (\%) of bacterial community and significant differences between batches and family/genus of ostrich meat after vacuumed, refrigerated storage.

\begin{tabular}{|c|c|c|c|}
\hline Family/Genus & $\begin{array}{l}\text { Batch I } \\
\text { (August) }\end{array}$ & $\begin{array}{c}\text { Batch II } \\
\text { (October) }\end{array}$ & $\begin{array}{l}\text { Batch III } \\
\text { (March) }\end{array}$ \\
\hline Vibrionaceae/Photobacterium & $84.55 \pm 1.53 \mathrm{Cb}$ & $89.74 \pm 2.87 \mathrm{Cb}$ & $56.09 \pm 12,81 \mathrm{Da}$ \\
\hline Bacteroidaceae/Bacteroides & $0.35 \pm 0.49^{\mathrm{Aa}}$ & $0 \pm 0^{\mathrm{Aa}}$ & $0 \pm 0^{\mathrm{Aa}}$ \\
\hline Carnobacteriaceae/Carnobacterium & $1,00 \pm 0,42 \mathrm{Aa}$ & $2.98 \pm 0.52 \mathrm{ABa}$ & $12.21 \pm 4.6^{\mathrm{BCb}}$ \\
\hline Lactobacillaceae/Lactobacillus & $3.70 \pm 1.41 \mathrm{Ba}$ & $4.61 \pm 3.18^{\mathrm{Ba}}$ & $2.11 \pm 0.13 \mathrm{Aa}$ \\
\hline Carnobacteriaceae/Other & $0 \pm 0^{\mathrm{Aa}}$ & $0 \pm 0^{\mathrm{Aa}}$ & $15.08 \pm 6.68^{\mathrm{Cb}}$ \\
\hline Enterobacteriaceae/Other & $0 \pm 0^{\mathrm{Aa}}$ & $0 \pm 0^{\mathrm{Aa}}$ & $4.09 \pm 1.24 \mathrm{ABb}$ \\
\hline Enterobacteriaceae/Serratia & $0.84 \pm 0.59 \mathrm{Aa}$ & $0 \pm 0^{\mathrm{Aa}}$ & $0 \pm 0^{\mathrm{Aa}}$ \\
\hline Enterococcaceae/Vagococcus & $0 \pm 0 \mathrm{Aa}$ & $1.35 \pm 1.9^{\mathrm{Aa}}$ & $0 \pm 0^{\mathrm{Aa}}$ \\
\hline Streptococcaceae/Lactococcus & $0 \pm 0^{\mathrm{Aa}}$ & $0 \pm 0^{\mathrm{Aa}}$ & $3.33 \pm 0.91 \mathrm{ABb}$ \\
\hline Leuconostocaceae/Weissella & $0.84 \pm 0.12 \mathrm{Aa}$ & $0.62 \pm 0.66^{\mathrm{Aa}}$ & $0.10 \pm 0.01 \mathrm{Aa}$ \\
\hline Shewanellaceae/Shewanella & $1.43 \pm 0.47^{\mathrm{Ab}}$ & $0 \pm 0^{\mathrm{Aa}}$ & $0 \pm 0^{\mathrm{Aa}}$ \\
\hline Unidentified & $4.86 \pm 1.65^{\mathrm{Bb}}$ & $0.21 \pm 0.3^{\mathrm{Aa}}$ & $6.01 \pm 1.00 \mathrm{ABCb}$ \\
\hline
\end{tabular}

Values are mean \pm standard errors; ${ }^{\mathrm{a}-\mathrm{b}}$ Means with different letters under different batches in the same row are significantly different $(p<0.05)$; ${ }^{A-D}$ Means with different letters under different family/genus in the same column are significantly different $(p<0.05)$. Data are mean \pm standard deviation.

\section{Discussion}

Even though the nutritional value of ostrich meat is well documented, not enough information is available on the microbial quality and shelf life, especially of the refrigerated vacuum-packaged ostrich fillet and steak form, which are most frequently purchased in development countries. Thus, improvement of the microbiological quality and extension of 
shelf life of retail ostrich meat is crucial, both for the local markets and for export [4,5,7]. It is known that the growth of microorganisms and their metabolic activity can significantly affect the quality of packaged raw meat stored under refrigerated conditions and its shelf life. Regarding ostrich meat, the relatively high $\mathrm{pH}$ is a supporting factor for rapid microbial spoilage under certain packaging conditions $[6,8,9,17]$. Therefore, the analysis of microbial counts and changes in the community composition related to the packaging methods, period, and temperature of raw meat storage may contribute to the development of effective methods of inhibiting specific spoilage and extending the shelf life of retail ostrich meat products.

In this study, utilising $16 \mathrm{~S}$ rDNA sequencing we investigated the microbial community composition and determined the predominant microflora occurring in three different batches of retail vacuum-packed ostrich meat acquired over several months (August, October, March). The culture-dependent method was also used for the enumeration of total initial numbers of common spoilage bacteria of raw ostrich meat among tested manufacturing batches, and their differences after 14 days of VP storage were also compared.

Using the enumeration method, we showed that the initial population of Photobacterium spp., LAB, Brochotrix spp., Pseudomonas spp., and Enterobacteriaceae in ostrich meat was relatively similar between the production batches. In line with many reports, the initial population of the indigenous microflora on raw poultry meat has consisted of Brochotrix spp., Pseudomonas spp., LABs, Enterobacteriaceae $[13,14,31,32]$ and to be similar to that red meat [33]. Surprisingly, Photobacterium spp. was the predominant genus in both initial and after 14 days of meat storage in VP and the total count of its was significantly higher in batch I (August) and batch II (October). At the end of the storage, the count of Photobacterium spp. reached above $7 \log \mathrm{CFU} / \mathrm{g}$, which is commonly reported as the microbial spoilage threshold causing sensorial deterioration such as the off-odours and slime [34,35]. Members of this genus are not often identified using the culture-dependent method; therefore, the mechanism underlying meat spoilage by Photobacterium has not been clarified. Moreover, the results of the enumeration counts revealed also the dominance of the LAB population at the beginning and after 14 days of meat storage, which is in agreement with previous studies on poultry meat [36-38], beef [11,15], and pork [19,39]. In our study, the initial counts of LAB (2.75-3.56 log CFU/g) were similar to those found in fresh ostrich steak (2-4 $\log$ CFU/g and $2.9 \log$ CFU/g) by Otremba et al. [18] and Fernandez-Lopez, [17], respectively. These results were also consistent with those of Jouki and Yazdi [39], who reported a $3.8 \log$ CFU/g of initial LABs count in fresh ostrich meat. On the other hand, a significantly higher initial LABs count of ostrich steak was reported by Alonso-Calleja et al. [6] with a range of 6.5-7.8 log CFU/g in retail ostrich steaks in Spain. In our study, the LAB population showed a significant increase in all packages above $7 \log \mathrm{CFU} / \mathrm{g}$ at the end of storage time (14 days), which can be associated with initial meat spoilage, especially with sensory deterioration [34]. Interestingly, Alonso-Calleja et al. [6] reported that samples of retail ostrich meat with a higher level of LABs than $7 \log C F U / g$ showed a non-repulsive and slight acid odour after 7 days of packaging. Moreover, none of the samples with $<7 \mathrm{log}$ $\mathrm{CFU} / \mathrm{g}$ of LABs count had any off-odour in VP meat, even when higher than $8 \log \mathrm{CFU} / \mathrm{g}$.

In our study, the initial count of Enterobacteriaceae as the indicator of meat contamination was relatively low in all batches in comparison to ostrich steaks (5.4-6.7 log CFU/g) from retail outlets in Spain [6]. It is known that the initial contamination of meat can influence the spoilage dynamics during storage. Similar results were also presented by Angulo et al. [40], who found an average of $6.78 \mathrm{log}$ CFU/g for Enterobacteriaceae in refrigerated VP ostrich steaks in Spain. Additionally, Fernandez-Lopez et al. [17] showed that Enterobacteriaceae counts in ostrich meat stored under aerobic conditions, VP, or MAP and $\mathrm{MAP}+\mathrm{CO}$ reached an average value of $7.0 \pm 0.2 \mathrm{log} \mathrm{CFU} / \mathrm{g}$ at the end of the storage period (18 day). Under aerobic conditions, the predominant spoilage microorganism in meat and poultry is Pseudomonas spp. [8,26,38]. Alonso-Calleja et al. [6] reported a range of 5.0-7.2 log $\mathrm{CFU} / \mathrm{g}$ for Pseudomonas spp. in fresh ostrich steaks, which is much higher than the initial range of $<1.00-1.85 \log \mathrm{CFU} / \mathrm{g}$ found in our study between individual batches. The higher 
initial count of Pseudomonas spp. (3.12 log CFU/g and $3.0 \mathrm{log}$ CFU/g) in ostrich meat was also reported by Jouki and Yazdi [39], and Bingol and Ergun [7]. Our results showed that VP limited the growth of Pseudomonas spp., which ranged from $1.48 \mathrm{log}$ CFU/g to $1.73 \mathrm{log}$ $\mathrm{CFU} / \mathrm{g}$ in batch I and batch II, respectively. A significantly higher Pseudomonas count of VP ostrich steaks was reported by Alonso-Calleja et al. [6] after 7 days of storage as well as by Jouki and Yazdi [39] at the end of storage (day 21). The initial number of Brochothrix spp. ranged from 1.8 to $2.3 \log \mathrm{CFU} / \mathrm{g}$ and fell within the range of values reported by other authors for unpackaged ostrich meat after slaughter $[8,9,17,18]$ and a slight growth was observed in VP meat after 14 days of storage. As mentioned by Pennacchia et al. [15], the growth of both Pseudomonas spp. and B. thermosphacta was effectively limited in VP chilled beef, as compared to the MAP $[11,13,23,33]$.

In the aforementioned studies, the microbiological characteristics of ostrich meat under different package methods or storage conditions were determined using a culturedependent technique, assessing the counts and viability of bacteria in the sample. It should be noted that culturable microorganisms represent only a small fraction of the entire microbial diversity and the culture-dependent method is not suitable to investigate changes in the bacterial communities during storage of meat products under different conditions. Currently, the rapid development of a high-throughput sequencing (HTS) approach is becoming more widely used to adequately characterise the composition of bacterial communities and their diversity during the storage of raw meat under different conditions $[25,38]$.

In our study, the amplicon sequencing of the V3/V4 region of the $16 \mathrm{~S}$ rDNA gene was applied to investigate the bacterial community composition and diversity of VP meat (fillet and steak portion) after 14 days of storage. Nine families were found in the microbiota in VP ostrich meat and the vast majority of detected sequences belonged to the genus of Photobacterium, Carnobacterium, Lactobacillus, and Enterobacteriaceae family (Table 4). A relatively taxonomically similar composition was obtained regardless of the manufacturing batches of both fillet and steak, but relative differences in the abundance of several bacterial genera between the tested batches were observed. Our results showed that Photobacterium genus was occurred in all samples from meat with a relative abundance from $56 \%$ to $89 \%$ dependent on the manufacturing batches, indicating a potential contribution to the spoilage of ostrich meat. The members of this genus are considered dominant spoilagerelated bacteria of refrigerated fish and seafood products [41,42] due to their ability to produce biogenic amines such as putrescine, tyramine, and cadaverine that can lead to fish poisoning [43]. Recently, based on culture-independent approaches, the presence of Photobacterium spp. was reported on the vacuum and air-stored beef [15] and modifiedatmosphere-packaged poultry [27,35], pork [21,44], and minced beef [26]. Together with this, our results showed that Photobacterium spp. was also present in raw ostrich meat, which could indicate that this genus is not characteristic only for marine species but is rather a widespread issue linked with the meat and poultry industry [27]. Several reports indicate that the source of Photobacterium in all kinds of meat could be highly associated with contamination via air or water during slaughtering and subsequent meat processing [27,34]. On the other hand, Hilgarth et al. [35] suggested that the presence of Photobacterium could be linked with livestock before the slaughtering process because this bacteria genus is an indigenous member of the animal gut microbiome. Moreover, Photobacterium may grow independent of the packaging method, and according to the study of Höll et al. [45], the modified atmosphere composition and vacuum packages, as well as marinating used to extend the shelf-life of meat and fish, are inadequate to restrict spoilage-associated Photobacterium in meat. Thus far, the mechanism underlying spoilage by this genus has not been clarified. Thus, further studies should be conducted to discover the source of the initial bacterial contamination of the meat and to know the mechanisms of Photobacterium adaptation to the respective storage conditions. To the best of our knowledge, this is the first report that detected the presence of Photobacterium in chilled ostrich meat packaged in a vacuum using a culture-independent approach. 
Psychrotrophic LABs are the prevailing spoilage organisms in packaged cold-stored meat products. [11,15,36]. Particularly, Leuconostoc, Carnobacterium, Lactobacillus, Lactococcus, and Weissella are the most abundant LAB genus associated with the spoilage of refrigerated and/or chilled vacuum-packaged beef $[10,11,15,33]$, pork $[19,20,46]$, and poultry meat $[8,28]$. LAB are recognised as important competitors in raw meat under VP and MAP conditions $[10,20,23]$ and have the potential to cause spoilage of raw meat by discolouration or production of off-odour compounds $[6,8,16,33]$. It has been shown that their relative abundance is dependent on the type of meat and preservation technology as well as interspecies interactions [26,47]. In our study, $16 \mathrm{~S}$ rDNA sequencing results showed that the composition of $\mathrm{LAB}$ was more diverse between manufacturing batches. A relatively high abundance of the Carnobacteriaceae family including Carnobacterium genus was detected in both the fillet and the steak of batch II (October) and III (March), whereas Lactobacillus became a common genus in all samples of ostrich meat after 14 days of storage. Previous reports showed that Lactobacillus spp., Carnobacterium spp., and Weissella spp. were the dominant bacterial communities during storage in vacuum-packed chilled pork [20,46], lamb [47-49], and beef $[10,11,33,50]$. Our study confirmed the prevalence of these genera in ostrich meat after 14 days of storage. Wang et al. [51] demonstrated that Lactococcus spp. were dominant bacteria at the end of the shelf life of poultry meat under modified-air packaging (MAP). Similar results were reported by Bingol and Ergun [7] regarding ostrich meat packaged under a modified atmosphere (MAP).

In our study, Carnobacterium spp. was the dominant genus of the LAB population in all tested manufacturing batches after 14 days of storage. Carnobacterium similar to other members of the LAB population is facultative anaerobic bacteria that can adapt to the environment of vacuum [22,31,52]. The significantly high abundance of Carnobacteriaceae observed in batch III (March) may be related to the initiation of the meat sensory deterioration process. On the other hand, relative higher Carnobacterium spp. in batch III can be associated with an initial higher count of this genus in fresh ostrich meat. In lamb steaks packaged in a vacuum pouch (VAC) with a VP machine and storage under $4{ }^{\circ} \mathrm{C}$ for 21 days, the significant growth of $C$. divergenus and C. maltaromaticus outcompeted the other microbial population and became the dominant bacteria in the latter period of storage was reported by Wang et al. [48]. The two aforementioned species are recognised as predominant species on raw meat regardless of the packaging conditions [14,53-55]. They have been found in air and VP, and are associated with the spoilage of fresh and chilled meat $[11,48,56]$. The presence of Carnobacteriaceae abundance as the predominant population at day $14(14.54 \%)$ and day $21(3.4 \%)$ was also observed in VP chilled pork [20]. In beef steak stored under vacuum, Carnobacterium spp. was detected most frequently in the last days of storage with an abundance of $100 \%$ after 20 days [15]. According to the sensory evaluation, Jääskeläinen et al. [54] reported that high oxygen MAP beef was spoiled over 10 days earlier than the VP beef. Moreover, LAB species are considered to be important for preventing the growth of other spoilage-related bacteria [56,57] due to their ability to produce antibacterial substances such as hydrogen peroxide, lactic acid, and bacteriocins [58]. Lactobacillus spp. acts as competitive microflora in meat and meat products, extending their shelf life by competing with pathogens such as L. monocytogenes, inhibiting their excessive growth $[58,59]$. The presence of Lactobacillus spp. in ostrich meat portions may be associated with the production of lactic acid, which inhibits the growth of spoilage-related bacteria under vacuum-packed storage $[13,16,26]$. A relatively high abundance of Carnobacterium spp. and other members of the Carnobacteriaceae family in batch III (March) and the simultaneous decrease of Photobacterium spp. abundance might be due to the competitive growth of Carnobacterium spp. or its inhibitory activity towards Photobacterium during the late phase of meat storage.

Höll et al. [31] reported that in high $\mathrm{O}_{2} \mathrm{MAP}$ at $4{ }^{\circ} \mathrm{C}$ Brochothrix thermosphacta were identified in the chicken breast as typical representative meat spoiling bacteria. $B$. thermosphacta is one of the main spoilers in raw meat packaged in a vacuum or modified atmosphere [60]. It has been reported that $B$. thermosphacta can grow in meat both under 
aerobic and anaerobic conditions [6,8,36,38,60]. Jääskeläinen et al. [54] showed that the abundance of $B$. thermosphacta was higher in high $\mathrm{O}_{2} M A P$ at $6{ }^{\circ} \mathrm{C}$ than in VP beef meat. Recently, Chen et al. [36] reported that Brochothrix was the dominant genus in fresh roast duck after 7 days of storage under overwrapped packaging (OWP). In our study, the initial cell count of Brochothrix spp. in ostrich meat was relatively low $(<2 \log$ CTU $/ g)$, and similar results were also observed in VP meat after 14 days of storage. The $16 \mathrm{~S}$ rDNA data showed that the relative abundance of Brochothrix spp. was found to be below the detection limit, which indicates that this genus did not belong to ESO in our experiment. Thus, our results confirm the previous finding $[6,8,17]$ that Brochothrix spp. are not an important contributor to the spoilage of VP ostrich meat. Our study shows how sequencing and the commonly used culture-dependent method for detection of metagenome result in different outcomes concerning the abundance of bacterial composition. This may be due to DNA extraction or PCR bias in the meat matrix in which different species are present at high levels and compete for $16 S$ rDNA amplification [11,15]. These results indicate the need to use both techniques simultaneously to study bacterial populations in meat and meat products comprehensively.

It is known that the presence of Enterobacteriaceae in raw meat is related to the initial contamination of animal carcasses during the slaughtering process and carcass handling [61,62]. A high number of this family is considered to be a hygiene indicator and has a high correlation with the sensory odour of the poultry [22,24,38,51]. Most of the studies have found many members of Enterobacteriaceae on raw beef $[10,11,14,26,50,55]$, pork [19-21,25], lamb [47-49], poultry [22,24,31,36], ostrich meat $[6,8,9,11]$ as well as on offal meat $[19,63]$. Identification of Enterobacteriaceae in refrigerated raw meat and meat products is of particular importance both for its high spoilage potential and for food safety concerns because some species are pathogens [12]. Serratia is the most commonly found genus in meat stored in air, VP, and MAP and plays an important role in the spoilage of meat, especially in the late phase of chilled meat storage $[14,15]$. Although Enterobacteriaceae has been found as one of the major bacteria in VP chilled meat $[6,33,39,48,53,64]$, using enumeration method and $16 \mathrm{~S}$ rDNA sequencing, the present study showed that its content was relatively lower in comparison to Photobacterium spp. and LAB population. The presence of the unclassified Enterobacteriaceae abundance (4.09\%) in batch III (March) can be associated with contamination of carcass during handling, but it was not consistent with results obtained from the culture-depended analysis; the initial count of Enterobacteriaceae in batch III was significantly lower than in batch I and batch II. This may be due to DNA extraction or PCR amplification bias [15]. Previous studies reported different counts of Enterobacteriaceae chilled beef [54], pork [25,56], lamb [47,48,62], ostrich [6-9], and poultry meat $[32,51,60]$ under different packaging methods and refrigerated storage. In our study, the relative abundance of this family in meat was relatively low $(<5 \%)$, and the cell count was below the limit of 6 logs CFU/g after 14 days of storage. Several previous studies have revealed that counts of $>7 \operatorname{logs} \mathrm{CFU} / \mathrm{g}$ are considered as the maximum value in a raw meat product at the end of its shelf life $[7,26,54]$. Regarding ostrich meat, the shelf life of meat storage under VP can be more than 10 days [7,18,26,54]. Although Enterobacteriaceae has been shown to be one of the major bacteria in VP chilled meat [15,61], in our experiment this family did not belong to the dominant ESO in ostrich meat. The role of this bacterial group as ESO becomes more significant if the storage temperature of the meat is abused [54].

Moreover, several low-abundance (i.e., Shewanella spp., Bacteroides spp.) animalorigin bacteria observed in the present study could be associated with contamination via faecal, air, and/or water during slaughtering and subsequent handling. For example, Bacteroides spp. detected in the steak (0.7\%) from batch I (August) was reported to be intestinal bacteria in livestock animals $[62,65]$. Similarly, Shewanella spp., which was isolated from the intestinal content of fish [61] in our study, was detected at a low level in both fillet (1.09\%) and steak (1.76\%) from batch I (August). In the food industry, the genus Shewanella is closely related to the Pseudomonas spp. and is considered the primary cause of meat spoilage during cold storage under vacuum $[13,17,65,66]$ or modified atmosphere 
packaging (MAP) [62]. Pseudomonas spp. was found as the dominant spoilage-related flora of raw poultry meat $[34,44,57,63,66]$ and MAP and VP meat products $[6,8,11,14,26,48]$; but its growth occurred more frequently in meat stored in the air than under vacuum, in line with its aerobic ability $[18,24,39,55]$. In our study, the relative abundance of Pseudomonas spp. in all tested manufacturing batches at the end of storage was found to be below to detected limit. Similar results were also found in the culture-dependent method (Table 2); the initial total number of Pseudomonas spp. was below to detection limit in both batch I (August) and batch II (October) $(<1.0 \log$ CTU /g), and insignificant low bacterial growth in VP ostrich meat after 14 days of storage at $4-5{ }^{\circ} \mathrm{C}$ was noticed. Ntzimani et al. [67] found inhibition of microbial growth, including Pseudomonas spp., on turkey fillets stored under air packaging (AP), VP, and vacuum skin pack (VSP) at $4{ }^{\circ} \mathrm{C}$. According to them, VSP is the most effective, followed by VP. In a culture-dependent study, Bingol and Ergun [7] reported that packaging of ostrich meat under a modified atmosphere (MAP) effectively inhibited the growth of Pseudomonas spp. with a simultaneous increase in LAB counts during the storage period. Thus, our results confirm the previous finding that Pseudomonas spp. is not an important contributor to the spoilage of VP ostrich meat.

\section{Conclusions}

The identification and monitoring of bacterial community dynamics during meat storage is important for identifying the predominant spoilage bacteria and optimising shelf-life strategies for raw ostrich meat products. In this study, 16S rDNA amplicon sequencing by employing a next-generation sequencing (NGS) approach was applied to determine the microbial community of VP chilled ostrich meat in three manufacturing batches produced in different periods to establish the range and diversity of this community. Nine main genera $(>0.5 \%)$ of bacteria were detected in refrigerated meat after 14 days of storage at $4-5{ }^{\circ} \mathrm{C}$. Photobacterium was the most prevalent genus detected in all samples of ostrich meat at the end of storage, which suggests that this genus may be contributing to meat deterioration and shortening of the commercial shelf life of ostrich meat under VP storage. To the best of our knowledge, this is the first report that detected the presence of Photobacterium spp. in chilled ostrich meat packaged under vacuum using a cultureindependent approach. Future research to confirm the potential link between the presence of Photobacterium spp. and the initiation of the VP ostrich meat deterioration is required.

Supplementary Materials: The following are available online at https://www.mdpi.com/article/10.339 0/pr9050803/s1. Table S1: Raw bioinformatics data of ostrich meat samples. Table S2: Microbial analysis of initial and VP bacterial population in refrigerated ostrich meat, separately for fillet and steak.

Author Contributions: Conceptualization, B.S. and K.L.; methodology, B.S., A.D., M.P., E.J.-K., K.L.; software, E.J.-K.; validation, M.P., A.D., E.J.-K.; formal analysis, E.J.-K. and B.S.; investigation, E.J.-K., B.S., M.P., A.D.; data curation, E.J.-K.; writing-original draft preparation, E.J.-K.; writing-review and editing, E.J.-K. and B.S.; visualization, E.J.-K. and B.S.; supervision, B.S. and K.L.; funding acquisition, K.L. All authors have read and agreed to the published version of the manuscript.

Funding: This study was supported by the European Union from the source of the European Regional Development Fund within the frame of the Smart Growth Operational Programme 2014-2020. The Project "Development of a comprehensive technology for premium class products from ostrich meat produced in Poland" implemented as part of the National Centre for Research and Development: The Fast Track (Project No. POIR.01.01.01-00-1132/17).

Institutional Review Board Statement: Not applicable.

Informed Consent Statement: Informed consent was obtained from all subjects involved in the study. Data Availability Statement: Not applicable.

Acknowledgments: We thank Danuta Kotyrba, from Wacław Dabrowski Institute of Agricultural and Food Biotechnology-State Research Institute for help in conducting statistical analysis. 
Conflicts of Interest: The authors declare that they have no known competing financial interests or personal relationships that could have appeared to influence the work reported in this manuscript.

\section{References}

1. Poławska, E.; Zdanowska-Sąsiadek, Ż.; Horbańczuk, J.; Pomianowski, J.F.; Jóźwik, A.; Tolik, D.; Raes, K.; De Smet, S. Effect of dietary organic and inorganic selenium supplementation on chemical, mineral and fatty acid composition of ostrich meat. CyTA J. Food 2016, 14, 84-87. [CrossRef]

2. Poławska, E.; Cooper, R.G.; Jóźwik, A.; Pomianowski, J. Meat from alternative species e nutritive and dietetic value, and its benefit for human health-A review. CyTA J. Food 2013, 11, 37-42. [CrossRef]

3. Al-Khalifa, H.; Al-Naser, A. Ostrich meat: Production, quality parameters and nutritional comparison to other types of meat. J. Appl. Poult. Res. 2014, 23, 784-790. [CrossRef]

4. Medina, F.X.; Aguilar, A. Ostrich meat: Nutritional, breeding and consumption aspects. The case of Spain. J. Food Nutr. Res. 2014, 2, 301-305. [CrossRef]

5. Horbańczuk, O.K.; Wierzbicka, A. Technological and nutritional properties of ostrich, emu, and rhea meat quality. J. Vet. Res. 2016, 60, 279-286. [CrossRef]

6. Alonso-Calleja, C.; Martınez-Fernández, B.; Prieto, M.; Capita, R. Microbiological quality of vacuum-packed retail ostrich meat in Spain. Food Microbiol. 2004, 21, 241-246. [CrossRef]

7. Bingol, E.B.; Ergun, O. Effects of modified atmosphere packaging (MAP) on the microbiological quality and shelf life of ostrich meat. Meat Sci. 2011, 88, 774-785. [CrossRef]

8. Capita, R.; Alvarez-Gonzales, T.; Alonso-Calleja, C. Effect of several packaging conditions on the microbiological, physicochemical, and sensory properties of ostrich steaks during refrigerated storage. Food Microbiol. 2018, 72, 146-156. [CrossRef] [PubMed]

9. Seydim, A.C.; Acton, J.C.; Hall, M.A.; Dawson, P.L. Effects of packaging atmospheres on shelf-life quality of ground ostrich meat. Meat Sci. 2006, 73, 503-510. [CrossRef] [PubMed]

10. Venter, P.; Shale, K.; Lues, J.F.R.; Buys, E.M. Microbial proliferation and mathematical indices of vacuum-packed bovine meat. J. Food Process Preserv. 2006, 20, 433-448. [CrossRef]

11. Ercolini, D.; Ferrocino, I.; Nasi, A.; Ndagijimana, M.; Vernocchi, P.; La Storia, A.; Laghi, L.; Mauriello, G.; Guerzoni, M.E.; Villani, F. Monitoring of microbial metabolites and bacterial diversity in beef stored under different packaging conditions. Appl. Environ. Microbiol. 2011, 77, 7372-7381. [CrossRef]

12. Bakhtiary, F.; Sayevand, H.R.; Remely, M.; Hippe, B.; Hosseini, H.; Haslberger, A.G. Evaluation of bacterial contamination sources in the meat production line. J. Food Qual. 2016, 39, 750-756. [CrossRef]

13. Odeyemi, O.A.; Alegbeleye, O.O.; Strateva, M.; Stratev, D. Understanding spoilage microbial community and spoilage mechanisms in foods of animal origin. Compr. Rev. Food Sci. Food Saf. 2020, 19, 311-331. [CrossRef]

14. Doulgeraki, A.I.; Ercolini, D.; Villani, F.; Nychas, G.E. Spoilage microbiota associated to the storage of raw meat in different conditions. Int. J. Food Microbiol. 2012, 157, 130-141. [CrossRef]

15. Pennacchia, C.; Ercolini, D.; Villani, F. Spoilage-related microbiota associated with chilled beef stored in air or vacuum pack. Food Microbiol. 2011, 28, 84-93. [CrossRef]

16. Chaillou, S.; Chaulot-Talmon, A.; Caekebeke, H.; Cardinal, M.; Christieans, S.; Denis, C.; Helene Desmonts, M.; Dousset, X.; Feurer, C.; Hamon, E.; et al. Origin and ecological selection of core and food-specific bacterial communities associated with meat and seafood spoilage. ISME J. 2015, 9, 1105-1118. [CrossRef]

17. Fernández-López, J.; Sayas-Barberá, E.; Munõz, T.; Sendra, E.; Navarro, C.; Pérez-Alvarez, J.A. Effect of packaging conditions on shelf-life of ostrich steaks. Meat Sci. 2008, 78, 143-152. [CrossRef]

18. Otremba, M.M.; Dikeman, M.E.; Boyle, E.A.E. Refrigerated shelf life of vacuum-packaged, previously frozen ostrich meat. Meat Sci. 1999, 52, 279-283. [CrossRef]

19. Benson, A.K.; David, J.R.; Gilbreth, S.E.; Smith, G.; Nietfeldt, J.; Legge, R.; Kim, J.; Sinha, R.; Duncan, C.E.; Ma, J.; et al. Microbial successions are associated with changes in chemical profiles of a model refrigerated fresh pork sausage during an 80-day shelf life study. Appl. Environ. Microbiol. 2014, 80, 5178-5194. [CrossRef]

20. Zhao, F.; Zhou, G.; Ye, K.; Wang, S.; Xu, X.; Li, C. Microbial changes in vacuum-packed chilled pork during storage. Meat Sci. 2015, 100, 145-149. [CrossRef]

21. Nieminen, T.T.; Dalgaard, P.; Björkroth, J. Volatile organic compounds and Photobacterium phosphoreum associated with spoilage of modified-atmosphere-packaged raw pork. Int. J. Food Microbiol. 2016, 218, 86-95. [CrossRef] [PubMed]

22. Oakley, B.B.; Morales, C.A.; Line, J.; Berrang, M.E.; Meinersmann, R.J.; Tillman, G.E.; Wise, M.G.; Siragusa, G.R.; Hiett, K.L.; Seal, B.S. The poultry-associated microbiome: Network analysis and farm-to-fork characterizations. PLoS ONE 2013, 8, e57190. [CrossRef] [PubMed]

23. Rouger, A.; Moriceau, N.; Prévost, H.; Remenant, B.; Zagorec, M. Diversity of bacterial communities in French chicken cuts stored under modified atmosphere packaging. Food Microbiol. 2018, 70, 7-16. [CrossRef] [PubMed]

24. Xiao, X.; Dong, Y.; Zhu, Y.; Cui, H.I. Bacterial diversity analysis of Zhenjiang Yao meat during refrigerated and vacuum-packed storage by 454 pyrosequencing. Curr. Microbiol. 2013, 66, 398-405. [CrossRef] [PubMed] 
25. Li, N.; Zhang, Y.; Wu, Q.; Gu, Q.; Chen, M.; Zhang, Y.; Sun, X.; Zhang, J. High-throughput sequencing analysis of bacterial community composition and quality characteristics in refrigerated pork during storage. Food Microbiol. 2019, 83, 86-94. [CrossRef] [PubMed]

26. Stoops, J.; Ruyters, S.; Busschaert, P.; Spaepen, R.; Verreth, C.; Claes, J.; Lievens, B.; Van Campenhout, I. Bacterial community dynamics during cold storage of minced meat packaged under modified atmosphere and supplemented with different preservatives. Food Microbiol. 2015, 48, 192-199. [CrossRef]

27. Hilgarth, M.; Fuertes-Perez, S.; Ehrmann, M.; Vogel, R.F. An adapted isolation procedure reveals Photobacterium spp. As common spoilers on modified atmosphere packed meats. Lett. Appl. Microbiol. 2018, 66, 262-267. [CrossRef]

28. Rouger, A.; Remenant, B.; Prévost, H.; Zagorec, M. A method to isolate bacterial communities and characterize ecosystems from food products: Validation and utilization in as a reproducible chicken meat model. Int. J. Food Microbiol. 2017, $247,38-47$. [CrossRef]

29. Lee, J.; Kim, T.; Choi, S.H.; Kim, B. Analysis of the bacterial microbiome in the small octopus, Octopus variabilis, from South Korea to detect the potential risk of foodborne illness and to improve product management. Food Res. Int. 2017, 102, 51-60. [CrossRef]

30. DeSantis, T.Z.; Hugenholtz, P.; Larsen, N.; Rojas, M.; Brodie, E.L.; Keller, K.; Huber, T.; Dalevi, D.; Hu, P.; Andersen, G.L. Greengenes, a chimera-checked $16 \mathrm{~S}$ rRNA gene 25 database and workbench compatible with ARB. Appl. Environ. Microbiol. 2006, 72, 5069. [CrossRef]

31. Höll, I.; Behr, J.; Vogel, R.F. Identification and growth dynamics of meat spoilage microorganisms in modified atmosphere packaged poultry meat by MALDI-TOF MS. Food Microbiol. 2016, 60, 84-91. [CrossRef]

32. Argyri, A.A.; Papadopoulou, O.S.; Nisiotou, A.; Tassou, C.C.; Chorianopolos, N. Effect of high-pressure processing on the survival of Salmonella Enteritidis and shelf-life of chicken fillets. Food Microbiol. 2018, 70, 55-64. [CrossRef]

33. Jones, R.J. Observations on the succession dynamics of lactic acid bacteria populations in chill-stored vacuum-packaged beef. Int J. Food Microbiol. 2004, 90, 273-282. [CrossRef]

34. Fuertes-Perez, S.; Hauschild, P.; Hilgarth, M.; Vogel, R.F. Biodiversity of Photobacterium spp. isolated from meats. Front. Microbiol. 2019, 10, 2399. [CrossRef]

35. Hilgarth, M.; Fuertes-Perez, S.; Ehrmann, M.; Vogel, R.F. Photobacterium carnosum sp. nov., isolated from spoiled modified atmosphere packaged poultry meat. Syst. Appl. Microbiol. 2018, 41, 44-50. [CrossRef]

36. Chen, X.; Zhao, J.; Zhu, L.; Luo, X.; Mao, Y.; Hopkins, D.L.; Zhang, Y.; Dong, P. Effect of modified atmosphere on shelf life and bacterial community of roast duck meat. Food Res. Int. 2020, 137, 109645. [CrossRef]

37. Björkroth, J.; Ristiniemi, M.; Vandamme, P.; Korkeala, H. Enterococcus species dominating in fresh modified-atmosphere-packaged marinated broiler legs are over-grown by Carnobacterium and Lactobacillus species during storage at 6 degrees C. Int. J. Food Microbiol. 2005, 97, 267-276. [CrossRef]

38. Liu, D.Y.; Xiao, X.; Wang, H.H.; Zhang, Q.Y.; Zou, Y.F. Characterization of the bacterial community of braised chicken, a specialty poultry product in China. Poult. Sci. 2019, 98, 1055-1063. [CrossRef]

39. Jouki, M.; Yazdi, F.T. The effect of gamma irradiation and vacuum packaging upon selected quality traits of refrigerated ostrich meat. Part 1. Microbial assessment. Anim. Sci. Pap. Rep. 2014, 32, 81-89.

40. Angulo, R.; Angulo, M. Comer carne de avestruz: +es una alternativa segura? Aliment. Noviembre 2001, 327, 51-54.

41. Dalgaard, P.; Mejlholm, O.; Christiansen, T.; Huss, H.H. Importance of Photobacterium phosphoreum in relation to spoilage of modified atmosphere-packed fish products. Lett. Appl. Microbiol. 1997, 24, 373-378. [CrossRef]

42. Ast, J.C.; Dunlap, P.V. Phylogenetic resolution and habitat specificity of members of the Photobacterium phosphoreum species group. Environ. Microbiol. 2005, 7, 1641-1654. [CrossRef] [PubMed]

43. Takahashi, H.; Ogai, M.; Miya, S.; Kuda, T.; Kimura, B. Effects of environmental factors on histamine production in the psychrophilic histamine-producing bacterium Photobacterium iliopiscarium. Food Control 2015, 52, 39-42. [CrossRef]

44. Nieminen, T.T.; Koskinen, K.; Laine, P.; Hultman, J.; Säde, E.; Paulin, L.; Paloranta, A.; Johansson, P.; Björkroth, J.; Auvinen, P. Comparison of microbial communities in marinated and unmarinated broiler meat by metagenomics. Int. J. Food Microbiol. 2012, 157, 142-149. [CrossRef]

45. Höll, I.; Hilgarth, M.; Geissler, A.J.; Behr, J.; Vogel, R.F. Prediction of in situ metabolism of photobacteria in modified atmosphere packaged poultry meat using metatranscriptomics data. Microbiol. Res. 2019, 222, 52-59. [CrossRef]

46. Tian, X.; Wu, W.; Yu, Q.; Hou, M.; Gao, F.; Li, X.; Dai, R. Bacterial diversity analysis of pork longissimus lumborum following long-term ohmic cooking and water bath cooking by amplicon sequencing of 16S rRNA gene. Meat Sci. 2017, 123, 97-104. [CrossRef]

47. Kim, C.; Stein, R.A.; Pao, S. Comparison of the microbial quality of lamb and goat meat acquired from internet and local retail markets. J. Food Prot. 2015, 78, 1980-1987. [CrossRef]

48. Wang, T.; Guo, H.; Zhang, H.; Ren, F.; Zhang, M.; Ge, S.; Luo, H.; Zhao, L. Dynamics of bacterial communities of lamb meat packaged in air and vacuum pouch during chilled storage. Food Sci. Anim. Resour. 2019, 39, 209-221. [CrossRef]

49. Gardner, A.; Mills, J.; Brightwell, G. The spoilage characteristics of Brochothrix thermosphacta and two psychrotolerant Enterobacteriaceae in vacuum packed lamb and the comparison between high and low pH cuts. Meat Sci. 2014, 97, 83-92.

50. De Filippis, F.; La Storia, A.; Villani, F.; Ercolini, D. Exploring the sources of bacterial spoilers in beef steaks by culture-independent high-throughput sequencing. PLoS ONE 2013, 8, e70222. [CrossRef] 
51. Wang, H.; Zhang, X.; Wang, G.; Jia, K.; Xu, X.; Zhou, G. Bacterial community and spoilage profiles shift in response to packaging in Yellow-Feather broiler, a high popular meat in Asia. Front. Microbiol. 2017, 8, 2588. [CrossRef]

52. Andreevskaya, M.; Johansson, P.; Laine, P.; Smolander, O.-P.; Sonck, M.; Rahkila, R.; Jääskeläinen, E.; Paulin, L.; Auvinen, P.; Björkroth, J. Genome sequence and transcriptome analysis of meat-spoilage-associated lactic acid bacterium Lactococcus piscium MKFS47. Appl. Environ. Microbiol. 2015, 81, 3800-3811.

53. Chenoli, E.; Macián, M.C.; Elizaquivel, P.; Aznar, R. Lactic acid bacteria associated with vacuum-packed cooked meat product spoilage: Population analysis by rDNA-based methods. J. Appl. Microbiol. 2007, 102, 498-508. [CrossRef]

54. Jääskeläinen, E.; Hultman, J.; Parshintsev, J.; Riekkola, M.-L.; Björkroth., J. Development of spoilage bacterial community and volatile compounds in chilled beef under vacuum or high oxygen atmospheres. Int. J. Food Microbiol. 2016, $223,25-32$.

55. Luong, N.-D.M.; Coroller, M.; Membre, J.-M.; Guillou, S. Spoilage of chilled fresh meat products during Storage: A quantitative analysis of literature data. Microorganisms 2020, 8, 1198. [CrossRef]

56. Danielski, G.M.; Imazaki, P.H.; de Andrade-Cavalari, C.M.; Daube, G.; Clinquart, A.; de Macedo, R.E.F. Carnobacterium maltaromaticum as bioprotective culture in vitro and cooked ham. Meat Sci. 2020, 162, 108035. [CrossRef]

57. Ercolini, D.; La Storia, A.; Villani, F.; Mauriello, G. Effect of a bacteriocin-activated polyethylene film on Listeria monocytogenes as evaluated by viable staining and epifluorescence microscopy. J. Appl. Microbiol. 2006, 100, 765-772. [CrossRef]

58. Cleveland, J.; Montville, T.J.; Nes, I.F.; Chikindas, M.L. Bacteriocins: Safe, natural antimicrobials for food preservations. Int. J. Food Microbiol. 2001, 45, 83-102. [CrossRef]

59. Dos Reis, F.B.; de Souza, V.M.; Thomaz, M.R.S.; Fernandes, L.P.; de Oliveirs, W.P.; de Martinis, E.C.P. Use of Carnobacterium maltaromaticum cultures and hydroalcoholic extract of Lippia sidoides Cham. against Listeria monocytogenes in fish model systems. Int. J. Food Microbiol. 2011, 146, 228-234. [CrossRef]

60. Rossaint, S.; Klausmann, S.; Kreyenschmidt, J. Effect of high-oxygen and oxygen-free modified atmosphere packaging on the spoilage process of poultry breast fillets. Poult. Sci. 2015, 94, 96-103. [CrossRef]

61. Al-Mutairi, M. The Incidence of Enterobacteriaceae Causing Food Poisoning in Some Meat Products. Adv. J. Food Sci. Technol. 2011, 3, 116-121.

62. De Jesús-Laboy, K.M.; Godoy-Vitorino, F.; Picento, Y.M.; Tom, L.M.; Pantoja-Feliciano, L.G.; Rivera-Rivera, M.J.; Andersen, G.I.; Dominguez-Bello, M.G. Comparison of the fecal microbiota in feral and domestic goats. Genes 2012, 3, 1-18. [CrossRef]

63. Esmer, O.K.; Irkin, R.; Degirmencioglu, N.; Degirmencioglu, A. The effect of modified atmosphere gas composition on microbial criteria, color, and oxidation values of minced beef meat. Meat Sci. 2011, 88, 221-226. [CrossRef] [PubMed]

64. Orkusz, A. Quality changes of goose breast meat during cold storage under modified atmosphere and vacuum. Eur. Poult. Sci. 2017, 81, 1-9.

65. Richard, G.P.; Watson, M.A.; Crane, E.J., III; Burt, I.G.; Bushek, D. Shewanella and Photobacterium spp. in Oysters and Seawater from the Delaware Bay. Appl. Environ. Microbiol. 2008, 74, 3323-3327. [CrossRef]

66. Liang, R.; Yu, X.; Wang, R.; Luo, X.; Mao, Y.; Zhu, L.; Zhang, Y. Bacterial diversity and spoilage-related microbiota associated with freshly prepared chicken products under aerobic conditions at $4{ }^{\circ} \mathrm{C}$. J. Food Prot. 2012, 75, 1057-1062. [CrossRef]

67. Ntzimani, A.G.; Paleologos, E.K.; Savvaidis, I.N.; Kontominas, M.G. Formation of biogenic amines and relation to microbial flora and sensory changes in smoked turkey breast fillets stored under various packaging conditions at $4{ }^{\circ} \mathrm{C}$. Food Microbiol. 2008, 25, 509-517. [CrossRef] 